\title{
Gillisia mitskevichiae sp. nov., a novel bacterium of the family Flavobacteriaceae, isolated from sea water
}

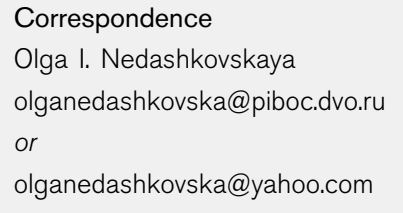

The genus Gillisia accommodates Gram-negative, strictly aerobic, heterotrophic, yellow-pigmented bacteria that are non-motile by gliding and belong to the family Flavobacteriaceae (Van Trappen et al., 2004). The strains of the single species of this genus, Gillisia limnaea, were isolated from microbial mats from Lake Fryxell in the McMurdo Dry Valleys, Antarctica. The genus Gillisia forms a phylogenetic cluster with the genera Mesonia, Salegentibacter and Psychroflexus.

During June 2000, we isolated an unknown bacterium from a sea-water sample collected in Amursky Bay, Gulf of Peter the Great, Sea of Japan. A polyphasic taxonomic study of strain KMM $6034^{\mathrm{T}}$, cultured on marine agar 2216 at $25^{\circ} \mathrm{C}$ for $48 \mathrm{~h}$, indicates that the isolate represents a novel species of the genus Gillisia, for which the name Gillisia mitskevichiae sp. nov. is proposed.

Genomic DNA extraction, PCR and sequencing of the $16 \mathrm{~S}$ rRNA gene followed previous procedures (Kim et al., 1998). The sequence data obtained were aligned with those of members of the family Flavobacteriaceae using PHYDIT version 3.2 (http://plaza.snu.ac.kr/ jchun/phydit/). Phylogenetic trees were inferred by using suitable programs of

Published online ahead of print on 20 August 2004 as DOI 10.1099/ ijs.0.63256-0.

tPresent address: Department of Microbiology, School of Bioscience and Biotechnology, Chungnam National University, Yusong, Daejon 305-764, Republic of Korea.

The GenBank/EMBL/DDBJ accession number for the 16S rRNA gene sequence of Gillisia mitskevichiae KMM $6034^{\top}$ is AY576655. the PHYLIP package (Felsenstein, 1993). Phylogenetic distances were calculated from the model of Kimura (1980) and trees were constructed on the basis of the neighbour-joining (Saitou \& Nei, 1987) and maximum-likelihood (Felsenstein, 1993) algorithms. Bootstrap analysis was performed with 1000 resampled datasets by using SEQBOOT and CONSENSE programs of the PHYLIP package.

Phylogenetic analysis of the almost-complete 16S rRNA gene sequence (1430 nucleotide positions) revealed that strain KMM $6034^{\mathrm{T}}$ was a member of the family Flavobacteriaceae and formed a distinct lineage within the genus Gillisia (Fig. 1). The level of 16S rRNA gene sequence similarity between strains KMM $6034^{\mathrm{T}}$ and G. limnaea LMG $21470^{\mathrm{T}}$ was $96 \cdot 7 \%$. 16S rRNA gene sequence similarity values of the strain studied with the next closest relatives Mesonia algae KMM $3909^{\mathrm{T}}$, [Cytophaga] latercula ATCC $23177^{\mathrm{T}}$, Salegentibacter salegens DSM 5424 ${ }^{\mathrm{T}}$, Psychroflexus torquis ACAM $623^{\mathrm{T}}$ and Kordia algicida OT-1 ${ }^{\mathrm{T}}$ were $91 \cdot 4$, $92 \cdot 2,93 \cdot 1,91 \cdot 4$ and $90 \cdot 5 \%$, respectively.

DNA was isolated following the method of Marmur (1961) and the G $+\mathrm{C}$ content of the DNA was determined by the thermal denaturation method (Marmur \& Doty, 1962). The DNA G+C content of KMM $6034^{\mathrm{T}}$ was $36 \cdot 4 \mathrm{~mol} \%$.

Analysis of fatty acid methyl esters was carried out according to the standard protocol of the Microbial Identification System (Microbial ID). The cellular fatty acids comprising more than $1 \%$ for strain $\mathrm{KMM} 6034^{\mathrm{T}}$ were straightand branched-chain unsaturated and saturated fatty acids, namely i-14:0 (1.2\%), i-15:1 (11.8\%), a-15:1 (2.4\%), 


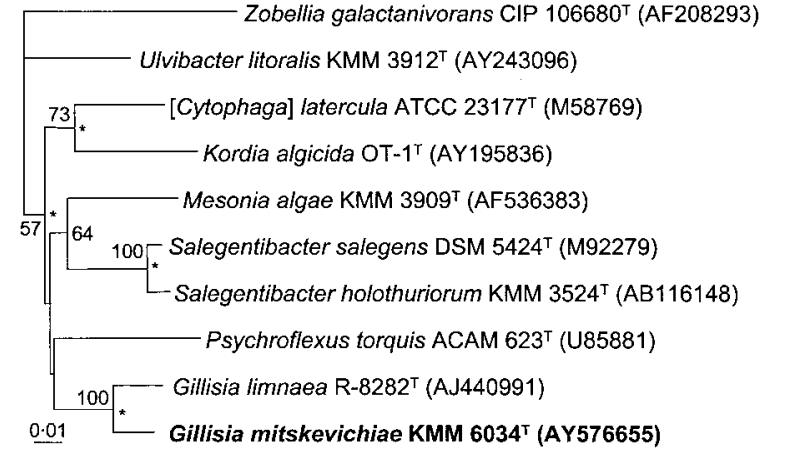

Fig. 1. Phylogenetic tree based on the 16S rRNA gene sequences of $\mathrm{KMM} 6034^{\top}$ and related members of the family Flavobacteriaceae. Asterisks indicate branches that were also recovered with the maximum-likelihood algorithm and numbers at nodes are levels of bootstrap support (\%) from 1000 resampled datasets. Bar, 0.01 substitutions per nucleotide position.

i-15:0 (7.5\%), a-15:0 (5.1\%), $15: 0(4 \cdot 4 \%), 15: 1 \omega 6 c$ $(1.9 \%), \quad \mathrm{i}-16: 1 \quad(6 \%), \quad \mathrm{i}-16: 0 \quad(9 \cdot 3 \%), \quad \mathrm{i}-15: 0 \quad 3-\mathrm{OH}$ $(1 \cdot 1 \%), 15: 02-\mathrm{OH}(2 \cdot 4 \%), \mathrm{i}-17: 1 \omega 9 c(4 \%), \mathrm{a}-17: 1 \omega 9 c$ $(2 \cdot 1 \%), 17: 1 \omega 6 c(4 \cdot 7 \%), \mathrm{i}-16: 03-\mathrm{OH}(7 \cdot 2 \%), 16: 03-$ $\mathrm{OH}(1 \cdot 2 \%), \mathrm{i}-17: 03-\mathrm{OH}(6 \cdot 7 \%), 17: 02-\mathrm{OH}(3 \cdot 8 \%)$, and summed feature $3(11 \cdot 1 \%)$, comprising i-15:0 2-OH and/or $16: 1 \omega 7 c$, which corresponds to the fatty acid composition of G. limnaea (Van Trappen et al., 2004). Both the strain studied and $G$. limnaea strains contained similar amounts of branched fatty acids ( $>65 \%$ of total).

Phenotypic analysis was performed by using previously described methods (Nedashkovskaya et al., 2003a, b). Gliding motility was determined as described by Bowman (2000).

The physiological, morphological and biochemical characteristics of strain KMM $6034^{\mathrm{T}}$ are listed in the species description and Table 1. The similarities in phenotypic characteristics support the inclusion of the strain studied in the genus Gillisia. However, strain KMM $6034^{\mathrm{T}}$ clearly differed from strains of $\mathrm{G}$. limnaea by the $\mathrm{NaCl}$ requirement for growth, growth at $12 \% \mathrm{NaCl}$, maximum growth temperature $\left(31^{\circ} \mathrm{C}\right)$, acid production from carbohydrates, utilization of mannitol and the ability to degrade casein, urea, DNA and Tweens 20 and 40 (Table 1).

The above-mentioned phenotypic features (Table 1) in association with molecular differences presented in this paper allow the differentiation of strain KMM $6034^{\mathrm{T}}$ from G. limnaea. Thus, we propose that strain KMM $6034^{\mathrm{T}}$ be placed in the genus Gillisia as the type strain of Gillisia mitskevichiae sp. nov.

\section{Description of Gillisia mitskevichiae sp. nov.}

Gillisia mitskevichiae (mit.ske'vi.chi.ae. N.L. gen. n. mitskevichiae of Mitskevich, in honour of Irina $\mathrm{N}$. Mitskevich, Russian marine microbiologist, for her contributions to the development of marine microbiology).
Table 1. Phenotypic characteristics that distinguish Gillisia mitskevichiae sp. nov. from G. limnaea

Data from Van Trappen et al. (2004) and this study. Strains of both species are Gram-negative and are positive for respiratory type of metabolism, oxidase, catalase and alkaline phosphatase activities, growth at $1-5 \% \mathrm{NaCl}$ and at $5-30{ }^{\circ} \mathrm{C}$, hydrolysis of gelatin and Tween 80 , utilization of glucose and sucrose and susceptibility to ampicillin, carbenicillin, lincomycin and oleandomycin. Strains of both species are negative for gliding motility, requirement for organic growth factors, flexirubin pigments, nitrate reduction, $\mathrm{H}_{2} \mathrm{~S}$, indole and acetoin production, degradation of agar, starch, cellulose (CM-cellulose, filter paper) and chitin, acid formation from arabinose, cellobiose, fucose, galactose, lactose, maltose, melibiose, raffinose, rhamnose, sorbose, xylose, inositol, mannitol, sorbitol, glycerol, adonitol, dulcitol and citrate, utilization of arabinose, lactose, mannose, inositol, sorbitol, malonate and citrate and susceptibility to gentamicin, kanamycin, neomycin and polymyxin B.

\begin{tabular}{|c|c|c|}
\hline Characteristic & $\begin{array}{l}\text { G. mitskevichiae } \\
\text { KMM } 6034^{\mathrm{T}}\end{array}$ & $\begin{array}{l}\text { G. limnaea } \\
(\mathbf{n}=3)\end{array}$ \\
\hline $\mathrm{Na}^{+}$requirement for growth & + & - \\
\hline \multicolumn{3}{|l|}{ Degradation of: } \\
\hline Casein & + & - \\
\hline DNA & + & - \\
\hline Urea & + & - \\
\hline Tween 20 & - & + \\
\hline Tween 40 & + & - \\
\hline \multicolumn{3}{|l|}{ Growth at: } \\
\hline $12 \% \mathrm{NaCl}$ & + & - \\
\hline $31{ }^{\circ} \mathrm{C}$ & + & - \\
\hline \multicolumn{3}{|l|}{ Acid from: } \\
\hline Glucose, sucrose & + & - \\
\hline$N$-Acetylglucosamine & + & - \\
\hline Utilization of mannitol & - & + \\
\hline $\begin{array}{l}\text { Susceptibility to streptomycin } \\
\text { and tetracycline }\end{array}$ & + & - \\
\hline DNA G $+\mathrm{C}$ content $(\mathrm{mol} \%)$ & $36 \cdot 4$ & $37-39$ \\
\hline
\end{tabular}

Cells are Gram-negative, strictly aerobic with respiratory metabolism, chemo-organotrophic, asporogenic rods, nonmotile by gliding, $0 \cdot 5-0 \cdot 7 \mu \mathrm{m}$ wide and $3-4 \mu \mathrm{m}$ long. Oxidase-, catalase-, urease- and alkaline phosphatasepositive. Colonies are circular, convex, shiny with entire edges, $1-3 \mathrm{~mm}$ in diameter on marine agar 2216. Produces yellow non-diffusible pigments. No growth is observed without $\mathrm{Na}^{+}$; grows at $1-12 \% \mathrm{NaCl}$. Flexirubin pigments are absent. Growth occurs at $4-31{ }^{\circ} \mathrm{C}$. The $\mathrm{pH}$ range of growth is $5 \cdot 5-10 \cdot 0$, with optimum growth occurring between $\mathrm{pH} 7 \cdot 6$ and $8 \cdot 3$. Casein, gelatin, DNA, urea and Tweens 40 and 80 are degraded; does not hydrolyse agar, starch, cellulose (CM-cellulose and filter paper), chitin or Tween 20. Forms acid from glucose, sucrose and $N$ acetylglucosamine, but not from arabinose, cellobiose, fucose, galactose, lactose, maltose, melibiose, raffinose, rhamnose, xylose, adonitol, dulcitol, glycerol, inositol or 
mannitol. Does not utilize arabinose, lactose, mannose, inositol, mannitol, sorbitol or citrate as sole sources of carbon and energy. Nitrate reduction is negative. $\mathrm{H}_{2} \mathrm{~S}$, indole and acetoin (Voges-Proskauer reaction) are not produced. Susceptible to ampicillin, carbenicillin, oleandomycin, lincomycin, streptomycin and tetracycline; resistant to kanamycin, benzylpenicillin, neomycin, gentamicin and polymyxin $\mathrm{B}$. The predominant cellular fatty acids are straight-chain unsaturated, branched-chain unsaturated and saturated, namely i-15:0 (7.5\%), a-15:0 (5.1\%), i- $15: 1(11 \cdot 8 \%), \mathrm{i}-16: 1(6 \%), \mathrm{i}-16: 0(9 \cdot 3 \%), \mathrm{i}-16: 03-\mathrm{OH}$ $(7 \cdot 2 \%), \mathrm{i}-17: 03-\mathrm{OH}(6 \cdot 7 \%)$ and summed feature 3 $(11 \cdot 1 \%)$, consisting of $\mathrm{i}-15: 02-\mathrm{OH}$ and/or $16: 1 \omega 7 c(64 \cdot 7 \%$ of total). The $\mathrm{G}+\mathrm{C}$ content of the DNA is $36 \cdot 4 \mathrm{~mol} \%$.

The type strain is KMM $6034^{\mathrm{T}}\left(=\mathrm{KCTC} 12261^{\mathrm{T}}=\mathrm{NBRC}\right.$ $100590^{\mathrm{T}}=\mathrm{LMG} 22575^{\mathrm{T}}$ ), isolated from sea-water collected in Amursky Bay, Gulf of Peter the Great, Sea of Japan.

\section{Acknowledgements}

This research was supported by grants of the Federal Agency for Sciences and Innovations of the Ministry for Education and Sciences of the Russian Federation (no. 2-2.16), the Russian Foundation for Basic Research (no. 05-04-48211) and the Program of Fundamental Investigations of the Presidium of the Russian Academy of Sciences 'Molecular and Cell Biology'. S. B. K., K.H.L. and K.S.B. are also grateful for support from the KRIBB Research Initiative Program.

\section{References}

Bowman, J. P. (2000). Description of Cellulophaga algicola sp. nov., isolated from the surfaces of Antarctic algae, and reclassification of
Cytophaga uliginosa (ZoBell and Upham 1944) Reichenbach 1989 as Cellulophaga uliginosa comb. nov. Int J Syst Evol Microbiol 50, 1861-1868.

Felsenstein, J. (1993). PHYLIP (phylogeny inference package), version 3.5c. Department of Genetics, University of Washington, Seattle, USA.

Kim, S. B., Falconer, C., Williams, E. \& Goodfellow, M. (1998). Streptomyces thermocarboxydovorans sp. nov. and Streptomyces thermocarboxydus sp. nov., two moderately thermophilic carboxydotrophic species isolated from soil. Int J Syst Bacteriol 48, 59-68.

Kimura, M. (1980). A simple method for estimating evolutionary rates of base substitutions through comparative studies of nucleotide sequences. J Mol Evol 16, 111-120.

Marmur, J. (1961). A procedure for the isolation of deoxyribonucleic acid from microorganisms. J Mol Biol 3, 208-218.

Marmur, J. \& Doty, P. (1962). Determination of the base composition of deoxyribonucleic acid from its thermal denaturation temperature. J Mol Biol 5, 109-118.

Nedashkovskaya, O. I., Suzuki, M., Vysotskii, M. V. \& Mikhailov, V. V. (2003a). Reichenbachia agariperforans gen. nov., sp. nov., a novel marine bacterium in the phylum Cytophaga-FlavobacteriumBacteroides. Int J Syst Evol Microbiol 53, 81-85.

Nedashkovskaya, O. I., Suzuki, M., Vysotskii, M. V. \& Mikhailov, V. V. (2003b). Vitellibacter vladivostokensis gen. nov., sp. nov., a new member of the phylum Cytophaga-Flavobacterium-Bacteroides. Int J Syst Evol Microbiol 53, 1281-1286.

Saitou, N. \& Nei, M. (1987). The neighbor-joining method: a new method for reconstructing phylogenetic trees. Mol Biol Evol 4, 406-425.

Van Trappen, S., Vandecandelaere, I., Mergaert, J. \& Swings, J. (2004). Gillisia limnaea gen. nov., sp. nov., a new member of the family Flavobacteriaceae isolated from a microbial mat in Lake Fryxell, Antarctica. Int J Syst Evol Microbiol 54, 445-448. 